\title{
PCBs and other toxicants in Mysis relicta
}

\author{
Marlene S. Evans, Ralph W. Bathelt \& Clifford P. Rice \\ Great Lakes Research Division, The University of Michigan, Ann Arbor, MI 48109, U.S.A.
}

Keywords: Mysidacea, chlorinated hydrocarbons, toxic cycling, amphipods

\begin{abstract}
This research considers the role of Mysis relicta in the recycling of toxic organics in the Lake Michigan ecosystem. Mysids were collected at a station $20 \mathrm{~km}$ offshore of Grand Haven, Michigan in spring, summer, and autumn and then size-sorted. In October 1980 and May 1981, plankton samples were collected in two size categories: $>78 \mu \mathrm{m}$ and $>156 \mu \mathrm{m}$. Mysid fecal pellets and Pontoporeia hoyi were collected in May 1981 while a fourhorn sculpin (Myoxocephalus quadicornis) was collected in October 1980. Concentrated extracts of all samples were analyzed for chlorinated hydrocarbons using electron capture gas chromatography. Toxic organics detected were, in order of concentration: PCB, DDE, dieldrin, $\gamma$-chlordane, and HCB. DDT, DDD, and $\alpha$-chlordane were detected less frequently. PCB concentrations in mysids were similar to those observed in their plankton diet and there was no evidence of increased bioaccumulation with increased mysid age. Dieldrin and DDE generally occurred in higher concentrations in older than in younger mysids. Dieldrin concentrations were lower in the plankton than in mysids. Certain toxicants (PCBs, DDD, dieldrin, and $\gamma$-chlordane) occurred in higher concentrations in Pontoporeia hoyi than in mysids. Concentrations in the sculpin generally were intermediate to those in amphipods and mysids. Our study suggests that mysids have a significant role in the recycling of toxic organics and that the characteristic pathways vary with the contaminant.
\end{abstract}

\section{Introduction}

The contamination of the Great Lakes ecosystem by toxic organics is a priority issue for the effective management of these immense bodies of fresh water (International Joint Commission 1979). Toxic organics such as PCBs, DDT, and dieldrin continue to enter these lakes from the land and the atmosphere (Glooschenko et al. 1976; Murphy \& Rzeszutko 1977; Strachan \& Huneault 1979) and, in association with sinking particulates, are deposited in sedimentary sinks (Frank et al. 1979, 1980; Rice et al. un publ. data). Transfer from surface inputs to sedimentary sinks is not direct and toxic organics are recycled through several biological compartments. Such recycling contributes to the persistence of toxicants in the Great Lakes ecosystem. Thus, although PCB usage was severely restricted in the early 1970s (Committee on the Assessment of Polychlorinated Biphenyls in the Environment 1979), Great Lakes fish continue to have high body burdens of the toxicant (Suns \& Rees 1978; Kaiser \& Valdmanis 1978).

This paper presents the results of a study investigating the role of Mysis relicta in the transport and recycling of toxic organics including $\mathrm{PCBs}$, in the Lake Michigan ecosystem. Data presented here are the first results obtained as a part of a continuing study of the environmental toxicology of this organism.

Our study focuses on Mysis relicta for several reasons. Mysids are a vital component of fish diets 


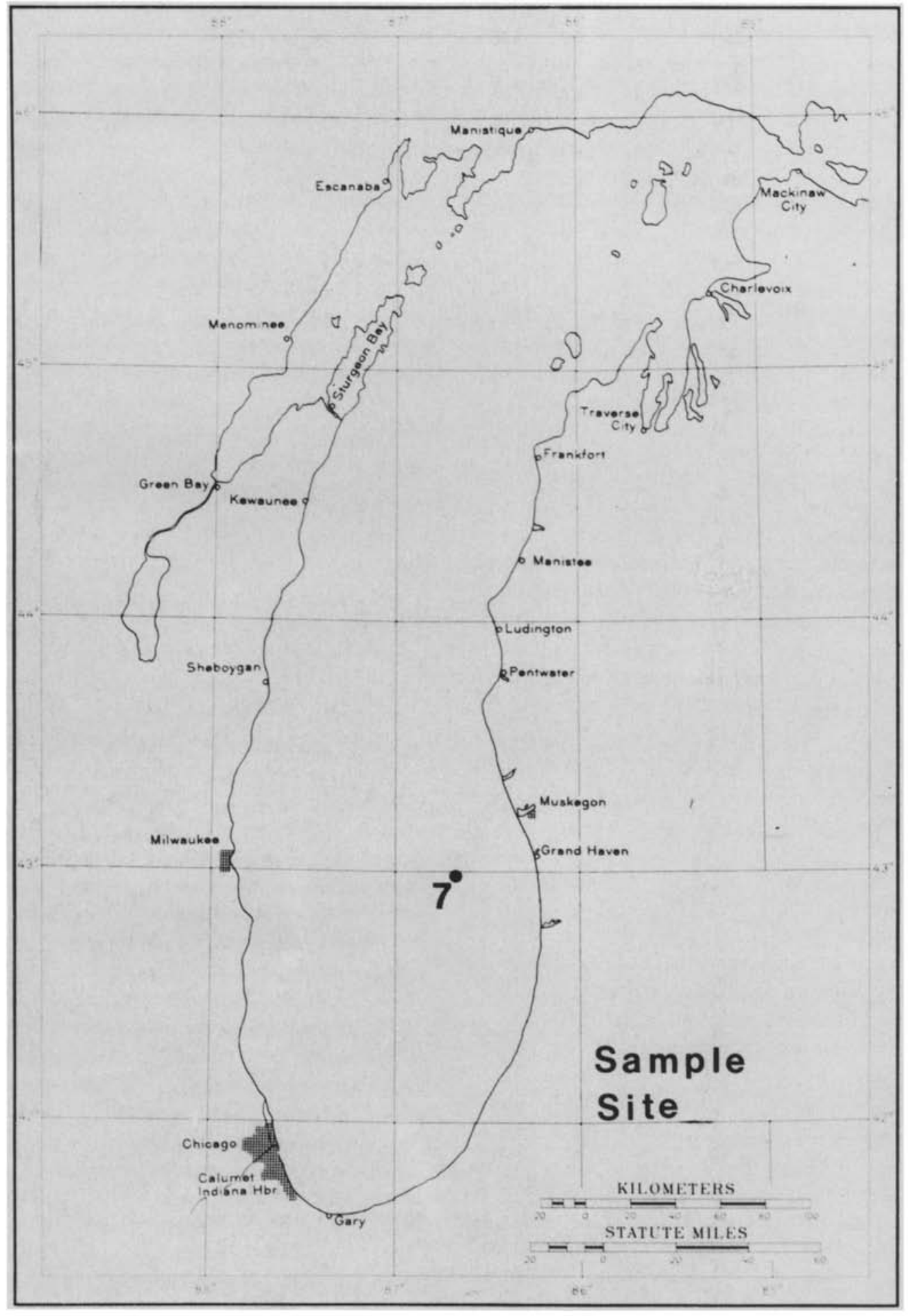

Fig. 1. Location of station 7 in Lake Michigan. 
including alewife (Janssen \& Brandt 1980), bloaters (Wells \& Beeton 1963), and young salmonids (McComish \& Miller 1976; Scott \& Crossman 1973). Several researchers suggest that fish obtain more of their body burden of toxicants from their diet than directly from the water (Macek \& Korn 1970; Weininger 1978). While it is known that Great Lakes fish contain high burdens of organic contaminants, little is known about contaminant concentrations in the invertebrates which compose fish diets. Thus our study fills a gap in the understanding of the trophic transfer of organic contaminants.

Mysids are a significant component of the Great Lakes invertebrate biomass accounting for an average standing stock of $1 \mathrm{~g} / \mathrm{m}^{2}$ versus about the same value for macrobenthos and for zooplankton (Mozley \& Howmiller 1977). Mysis relicta is a strong vertical migrator which inhabits the sediment water interface during daylight hours and moves into the metalimnion at night (Beeton 1960; Robertson et al. 1968) to feed on the plankton (Bowers \& Grossnickle 1978). As a consequence of this behavior, mysids have the potential for rapidly transporting toxic organics from the near-surface water to the sediments and vice versa. In this study we are considering transport both in mysid body tissue and through fecal pellet production.

\section{Materials and methods}

\section{Colleciion methods}

Samples were collected on three cruises during July 1980 , October 1980, and May 1981 at station 7 in Lake Michigan (Fig. 1) located approximately 20 $\mathrm{km}$ offshore from Grand Haven, Michigan. This station was also one of the sites of a Great Lakes Environmental Research Laboratory, NOAA, Ann Arbor (GLERL) sediment trap study. Samples collected by GLERL at station 7 provide an additional insight into the role of mysids and other zooplankton(Glover \& Evans 1981) in recycling toxic organics.

The July 1980 cruise was a preliminary study during which field and laboratory techniques were designed and tested. Mysids were collected during the daytime using an epibenthic sled equipped with a \#0 (569- $\mu \mathrm{m})$ mesh plankton net and glass cod end. Mysids collected on this first attempt were dead or in poor condition owing to severe abrasions inflict- ed when they were compressed against the sides of the net during sample collection. These collections were divided into three subsamples and placed in solvent-rinsed mason jars. These three replicates provided an estimate of the analytical error in determining contaminant concentrations.

During the October 1980 cruise the epibenthic sled was allowed to drift over the bottom rather than being towed. Mysids were generally in better condition than in July but mortality was still high. In May 1981, the sled again was used but the ship's winch modified so that the sled could be hauled in at about $20 \mathrm{~m} / \mathrm{min}$, thereby improving mysid survival. A fish trawl which was lined with a $\$ 000$ (1024$\mu \mathrm{m})$ net also collected mysids that were in excellent condition. Mysids also were collected from the metalimnion, at night, using a $\# 000$ and a $\# 0$ mesh plankton net in a series of tows from $40 \mathrm{~m}$ to the surface. The nighttime sampling yielded the greatest number of live mysids in excellent condition.

In October (day) and May (night) immediately after collection, mysids were placed in a 24-1 metal container filled with glass fiber filtered lake water collected from the hypolimnion. The metal container had previously been triple-rinsed with acetone and then with petroleum ether. Live mysids were transferred with all metal, pre-cleaned dip nets to another metal bucket and enumerated. These live mysids were then placed into a funnel-shaped trap similar to that used by Rosa (1976) to collect their fecal pellets. The trap was placed in a 120-1 metal can filled with glass fiber filtered lake water. It consisted of a wire basket (which retained the animals) attached to a metal funnel which guided settling materials into a mason jar. All parts of the collection apparatus were pre-cleaned with triple solvent rinses. Mysids were maintained at less than $6{ }^{\circ} \mathrm{C}$ while they released fecal pellets. Sufficient numbers of live mysids (approximately 1500; mean length $11.8 \mathrm{~mm}$ ) were collected only in May to obtain enough fecal pellets for toxic organic analysis.

After 4 (October) to 10 hours (May) mysids were siphoned from the wire basket into a pre-cleaned metal container using $1.27 \mathrm{~cm}$ inner diameter teflon tubing. The animals collected in October were divided into three size categories: $>10 \mathrm{~mm}, 7$ to 10 $\mathrm{mm}$, and $<7 \mathrm{~mm}$, placed in 7 dram brown glass vials, and frozen for later analysis. In May 1981 the animals were divided into four size categories; $<7$ 
$\mathrm{mm}, 7$ to $10 \mathrm{~mm}, 10$ to $14 \mathrm{~mm}$, and $>14 \mathrm{~mm}$. Females become reproductive at one year when they attain a length of 14 to $16 \mathrm{~mm}$ (Morgan \& Beeton 1978).

Plankton samples were collected from the upper $50 \mathrm{~m}$ of the water column in a series of tows using $\# 10(156-\mu \mathrm{m})$ and $\# 20(78-\mu \mathrm{m})$ mesh 50 -cm diameter plankton nets. Contents of the cod end were transferred to pre-cleaned mason jars and frozen for later toxic organic analysis. A single fourhorn sculpin (Myoxocephalus quadricornis) collected in October 1980 was retained for toxic organic analysis. Large numbers of live Pontoporeia hoyi were collected in May 1981 with the fish trawl (day) and also were retained for analysis. Only a small percentage of $P$. hoyi enter the water column at night (Wells 1968).

\section{Extraction and isolation of toxic organics}

The organochlorines examined in this study were the pesticides, p,p'-DDT, p,p'-DDE, p,p'-DDD, $\alpha$-chlordane, $\gamma$-chlordane, dieldrin, and hexachlorobenzene, and PCBs Aroclor 1242 and Aroclor 1254. Aroclor 1242 is the Monsanto Chemical Company, St. Louis, Mo., commercial name for their PCB product containing $42 \%$ chlorine by weight and Aroclor 1254 is their PCB product containing $54 \%$ chlorine by weight. Standards for the above listed compounds were obtained from the United States Environmental' Protection Agency (USEPA) Pesticide Repository Facility, Research Triangle Park, North Carolina.

In preparation for extraction, all samples except for the single sculpin collected during the October 1980 cruise were freeze-dried over a period of 24 to 48 hours. After freeze-drying the samples were ground to a smooth, homogenized paste in a solvent rinsed mortar and pestle. A $300 \mathrm{mg}$, or less, subsample of tissue was then transferred to a $12 \times$ $50 \mathrm{~mm}$ pre-extracted soxhlet thimble and extracted with $20 \mathrm{ml}$ of petroleum ether in a micro-soxhlet for 4 to 6 hours. Kuderna-Danish evaporative concentrators were subsequently used to concentrate the samples to less than $2 \mathrm{ml}$.

The sculpin sample was homogenized in a Waring blender and ground to a paste with a mortar and pestle. During the grinding sodium sulfate was added in a ratio of 4 parts sodium sulfate to 1 part tissue to absorb water. The entire fish was trans- ferred to a $33 \times 94 \mathrm{~mm}$ pre-extracted soxhlet thimble and extracted with a 50/50 mixture of hexane and acetone in a soxhlet for approximately $24 \mathrm{~h}$.

Substances in the samples which might interfere with the PCBs and related chlorinated hydrocarbon analyses were removed by an alumina clean-up procedure. This procedure consisted of eluting each sample (in $2 \mathrm{ml}$ or less) through $4.0 \mathrm{~g}$ of Woelm alumina (containing $6 \%$ water by weight) covered by approximately $1.5 \mathrm{~cm}$ of sodium sulfate in a $1 X$ $30 \mathrm{~cm}$ chromatogra phy column with $20 \mathrm{ml}$ of petroleum ether. The eluate was subsequently concentrated to less than $2 \mathrm{ml}$ for silicic acid fractionation.

To prevent interference between compounds during sample analysis with the gas chromatograph, toxic organic compounds in each of the samples were separated into four fractions using a silicic acid fractionating technique similar to that of $\mathrm{Bi}$ dleman et al. (1978). Three and a half grams of oven-dried silicic acid, which had been cooled for 1 $\mathrm{h}$ in a desiccator, were placed in amber vials and redried in an oven for $2 \mathrm{~h}$. After allowing the silicic acid to cool to room temperature in a desiccator, $100 \mu \mathrm{l}$ of pre-extracted water was added to each vial, and the vials were sealed. After allowing 1 to 3 $\mathrm{h}$ for equilibration, the silicic acid was transferred to pre-cleaned $1 \times 30 \mathrm{~cm}$ glass columns and topped with approximately $1.5 \mathrm{~cm}$ of sodium sulfate. The silicic acid was then rinsed with $20 \mathrm{ml}$ of methylene chloride which was forced through the column with purified nitrogen gas, followed by $20 \mathrm{ml}$ of petroleum ether. Before the last of the PE passed through the sodium sulfate layer the sample was quantitatively added to the top of the column. Once into the sulfate layer the sample was eluted with $120 \mathrm{ml}$ of $P E$ and three fractions $(0-10 \mathrm{ml}, 10-40 \mathrm{ml}$, and $40-120 \mathrm{ml}$ ) were collected using nitrogen gas to push the PE through the column at a rate of 1 $\mathrm{ml} / \mathrm{min}$. A final rinse of the column with $20 \mathrm{ml}$ of methylene chloride provided a fourth fraction. Care was taken in order to remove all traces of methylene chloride from fraction 4 since this material interferes with the electron capture detector. Evaporative concentrations with a higher boiling solvent, i.e. hexane, took care of this.

\section{Sample analysis}

Volumes for all fractions were adjusted to $2 \mathrm{ml}$ and 2 to $4 \mu \mathrm{l}$ subsample volumes were analyzed on a 
Varian 3700 gas chromatograph equipped with pulsed ${ }^{63} \mathrm{Ni}$ electron capture detectors. To confirm the results each sample was injected on both columns of the gas chromatograph. One column was a $2 \mathrm{~mm}$ i.d. $\times 1.8 \mathrm{~m}$ glass column packed with $5 \%$ SP-2100 (Supelco Inc., Bellefonte, PA) on 100/120 mesh Supelcoport, while the other glass column of the same dimensions was packed with $1.5 \% \mathrm{SP}$ $2250 / 1.95 \%$ SP-2401 on $100 / 120$ mesh Supelcoport. The instrumental conditions for both columns were, injector temperature $220^{\circ} \mathrm{C}$, column temperature $201{ }^{\circ} \mathrm{C}$, and detector temperature $350^{\circ} \mathrm{C}$. $\mathrm{K}$ nown standards were injected for comparison with the samples. A comparison of the samples to several Aroclors revealed that none of them precisely matched any one Aroclor. However, a mixture of Aroclor 1242 and 1254 provided the best match. Concentrations of toxic organics in the samples were calculated by comparison of peak heights or peak area of the sample to that of the standard. All of the final results were corrected by subtracting blank determinations for each of the analyzed components.

The presence of dieldrin in the samples was confirmed by the removal of the dieldrin peak from the fraction 4 chromatographic traces after acidification. Acidification was done by adjusting the sample volume to $2 \mathrm{ml}$, removing a $1 \mathrm{ml}$ aliquot, adding $1 \mathrm{ml}$ of concentrated sulfuric acid, and vigorously mixing for $2 \mathrm{~min}$. After mixing the samples were allowed to sit $\mathrm{l} \mathrm{h}$ before the organic layer was pipetted off for analysis. Samples containing significant amounts of interfering compounds, such as phthalates, were also acidified to remove the interference before quantification was attempted.

\section{Results}

The results for all the chlorinated hydrocarbon analyses of the biological materials are summarized in Fig. 2-5. The substances reported in the figures are: PCBs as Aroclors 1242 and 1254, the DDT family (DDT, DDD, and DDE) of compounds, dieldrin and HCB (hexachlorobenzene). Two major components of the chlordane family ( $\alpha$ - and $\gamma$-chlordane) were detected in nearly all the samples in at least trace amounts. When a toxic organic was present at or near the blank concentration, values are reported as less than the detection limit for that

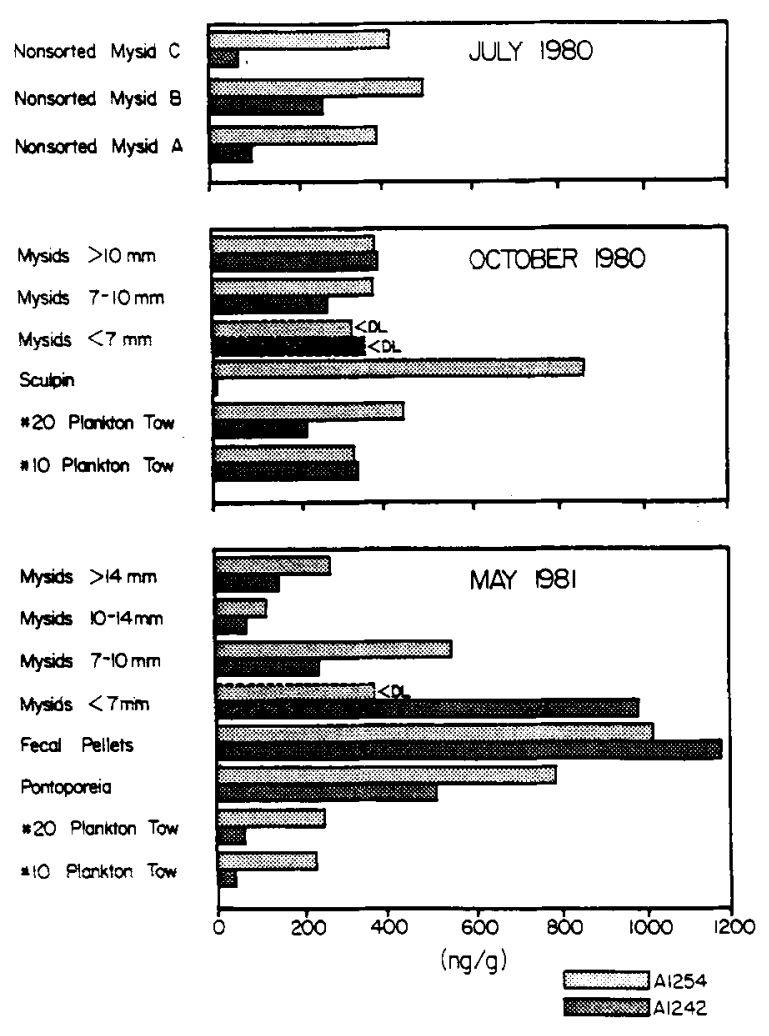

Fig. 2. Concentrations in ng/g dry weight of PCB Aroclors 1254 and 1242 in Mysis relicta, fecal pellets, plankton, Pontoporeia hoyi, and the sculpin by collection period.

analysis. Detection limit depended upon the compound and the amount of tissue analyzed. Low biomass of fecal pellets and mysids less than $7 \mathrm{~mm}$ in length reduced the sensitivity of certain analyses.

\section{PCB (Fig. 2)}

PCB Aroclors 1242 and 1254 were detected in mysids, plankton, the sculpin, and amphipods. Primarily because of the small sample sizes, levels were below detection limits for both Aroclors in $<7$ mm mysids collected in October 1980 and for mysids less than $7 \mathrm{~mm}$ in length collected in May 1981 (Aroclor 1254 only). Aroclor 1254 was the predominant form with the exception of mysids less than 7 $\mathrm{mm}$ in length in May 1981, mysid fecal pellets, and possibly adult mysids and the $>156-\mu \mathrm{m}$ plankton category in October 1980.

Aroclor 1254 concentrations in mysids ranged from $122 \mathrm{ng} / \mathrm{g}$ for the $10-14 \mathrm{~mm}$ mysids to a high of $545 \mathrm{ng} / \mathrm{g}$ for 7-10 mm mysids collected in May 


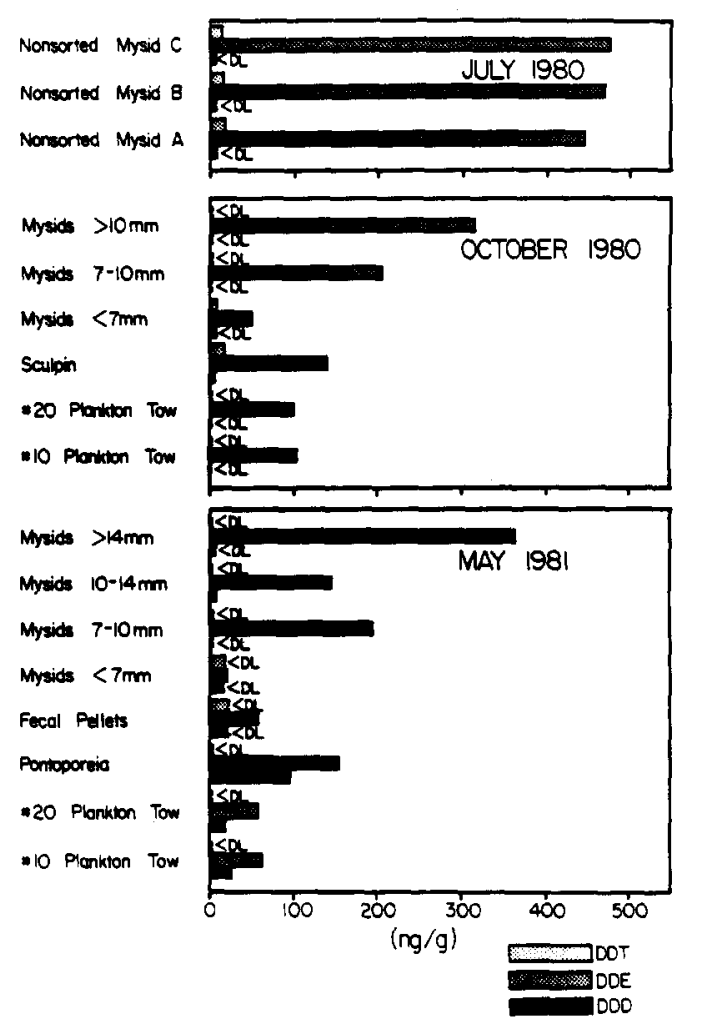

Fig. 3. Concentrations in ng/g dry weight of DDT, DDE, and DDD in Mysis relicta, fecal pellets, plankton, Pontoporeia hoyi, and the sculpin by collection period.

1981. There was no apparent trend for increasing or decreasing concentration of PCBs as a function of mysid age (size). PCB levels in mysids were similar to those observed in the $>156-\mu \mathrm{m}$ and $>78-\mu \mathrm{m}$ plankton categories. Fecal pellets, collected primarily from larger $(>10 \mathrm{~mm})$ mysids, contained high concentrations of PCBs (1022 ng Aroclor 1254/g; $1200 \mathrm{ng}$ Aroclor $1242 / \mathrm{g}$ ).

In October 1980, high concentrations of Aroclor $1254(868 \mathrm{ng} / \mathrm{g})$ were detected in the sculpin; conversely Aroclor 1242 occurred in low (14 ng/g) concentrations. In May 1981, with the exception of fecal pellets, the highest concentrations of PCBs were observed in Pontoporeia hoyi (792 ng Aroclor 1254/g; $513 \mathrm{ng}$ Aroclor 1242/g).

\section{$D D T, D D E$, and $D D D$ (Fig. 3)}

DDT concentrations were below PCB concentrations and frequently below detection limits. DDT was detected in mysids in July $1980,<7 \mathrm{~mm}$

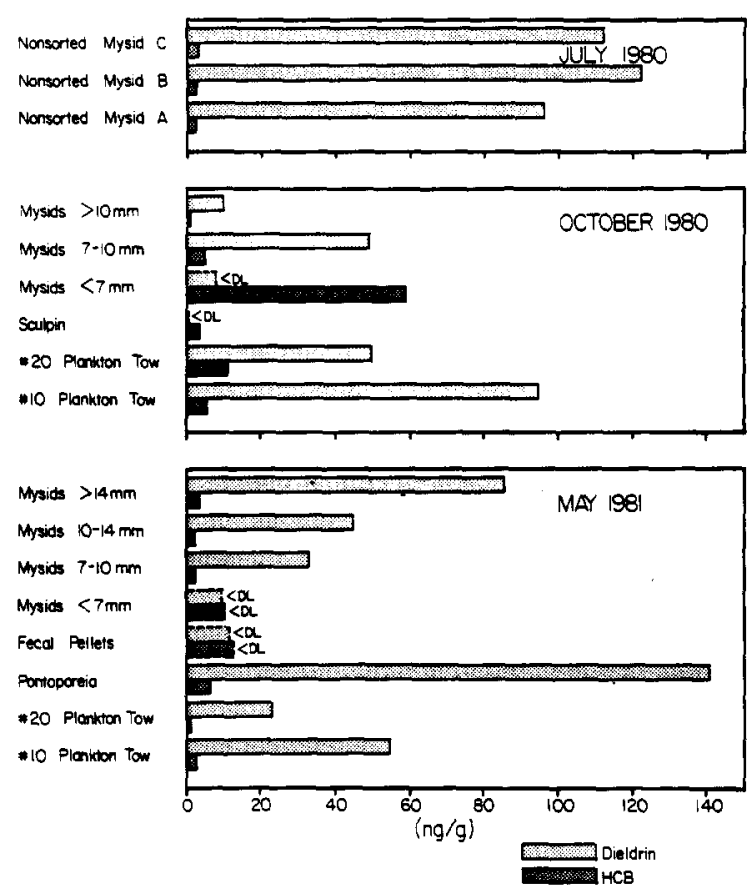

Fig. 4. Concentrations in $\mathrm{ng} / \mathrm{g}$ dry weight of dieldrin and HCB in Mysis relicta, fecal pellets, plankton, Pontoporeia hoyi, and the sculpin by collection period.

mysids in October 1980, and the sculpin in October 1980: concentrations were $<20 \mathrm{ng} / \mathrm{g}$.

DDE, the aerobic breakdown product of DDT (Matsumura 1975) was detected in all samples. Values were highest in mysids collected in July 1980 $($ mean $=414 \mathrm{ng} / \mathrm{g})$. There was evidence of increasing DDE concentration with increasing mysid age but more collections are required to confirm this apparent trend. With the exception of the smallest size category of mysids, DDE levels were higher in mysids than in the plankton collections. Fecal pellets contained low concentrations $(57 \mathrm{ng} / \mathrm{g}$ ) of DDE. Pontoporeia hoyi and the sculpin also had high concentrations of DDE (154 ng/g and 139 $\mathrm{ng} / \mathrm{g}$ respectively) in their tissue. Concentrations were greater than in the plankton but lower than in the mysids.

DDD, an anaerobic breakdown product of DDT, was detected in only a few samples. These included the sculpin $(6 \mathrm{ng} / \mathrm{g})$, Pontoporeia hoyi $(96 \mathrm{ng} / \mathrm{g})$, and the $>156-\mu \mathrm{m}(62 \mathrm{ng} / \mathrm{g})$ and $>78-\mu \mathrm{m}(57 \mathrm{ng} / \mathrm{g})$ plankton categories in May 1981. DDD was detected also in mysids $10-14 \mathrm{~mm}$ in length $(8 \mathrm{ng} / \mathrm{g}$ ) collected in May 1981. 

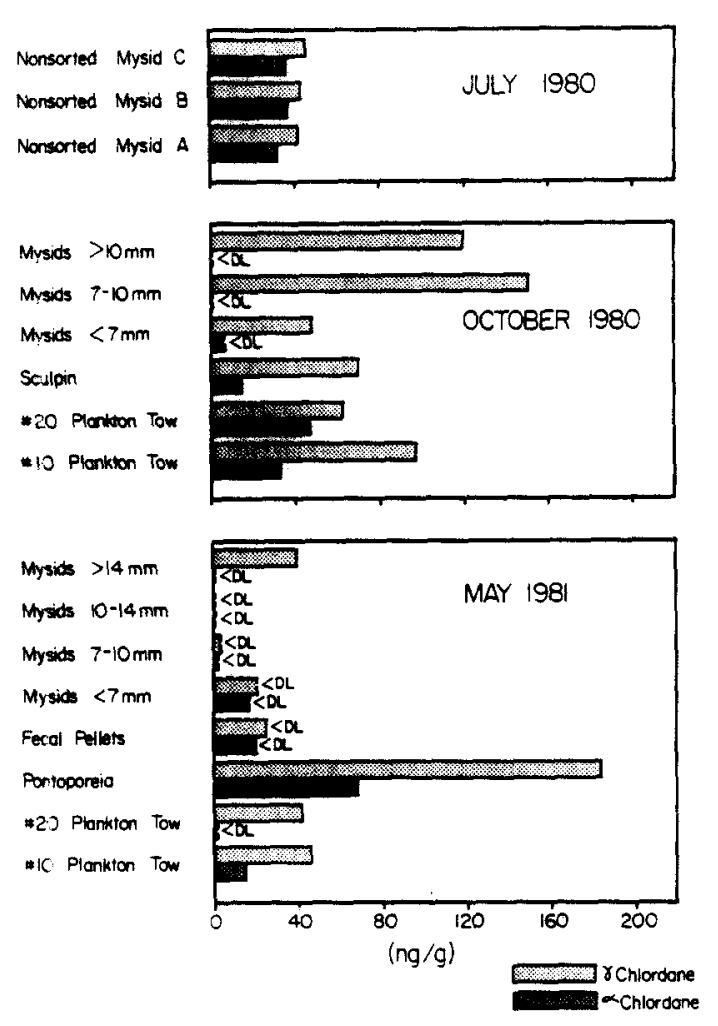

Fig. 5. Concentrations in $\mathrm{ng} / \mathrm{g}$ dry weight of $\alpha$ - and $\gamma$-chlordane in Mysis relicta. fecal pellets, plankton, Pontoporeia hoyi, and the sculpin by collection period.

\section{Dieldrin and $H C B$ (Fig. 4)}

Dieldrin occurred in high concentrations in mysids $(100 \mathrm{ng} / \mathrm{g})$ collected in July 1980 . Concentrations were lowest in mysids in October 1980 (10-43 $\mathrm{ng} / \mathrm{g}$ ) and intermediate in mysids collected in May 1981 (33-86 $\mathrm{ng} / \mathrm{g}$ ). In May, there was evidence of a trend for increasing dieldrin concentration with increasing mysid age.

Dieldrin concentrations in the $>78-\mu$ m plankton size category were lower than in the $>156-\mu \mathrm{m}$ plankton size category in both collection periods. In October plankton concentrations of dieldrin were greater than those observed in $>7 \mathrm{~mm}$ mysids. Dieldrin concentrations were higher in mysids and lower in the plankton in May 1981. Dieldrin was not detected in fecal pellets at this time. Pontoporeia hoyi had high concentrations of dieldrin (141 $\mathrm{ng} / \mathrm{g}$ ) while dieldrin was not detected in the sculpin.

$\mathrm{HCB}$ occurred in low concentrations $(<5 \mathrm{ng} / \mathrm{g})$ in all samples with the exception of immature mys- ids $(59 \mathrm{ng} / \mathrm{g}$ ) collected in October 1980 . HCB was also detected in the plankton, the amphipods, and the sculpin.

\section{$\alpha$-chlordane and $\gamma$-chlordane (Fig. 5)}

The $\gamma$-chlordane isomer predominated over the $\alpha$-isomer in all collections although the relative proportions of the two isomers varied from collection to collection and sampling period to sampling period. The two isomers occurred in similar concentrations (35 ng/g for $\alpha$-chlordane, $44 \mathrm{ng} \gamma$ chlordane/g) in July 1980 while the $\alpha$-chlordane isomer was not detected in mysids in October 1980 and the $\gamma$-isomer occurred in high concentrations $(72-151 \mathrm{ng} / \mathrm{g})$. In May 1981, $\gamma$-chlordane was detected only in mysids greater than $14 \mathrm{~mm}$ in length (41 ng/g).

The $\gamma$-isomer was detected in all plankton collections while the $\alpha$-isomer was not detected in the $>78-\mu \mathrm{m}$ plankton size category in May 1981. Chlordanes occurred in moderate concentrations in the sculpin (15 ng $\alpha$-chlordane/g; 70 ng $\gamma$-chlordane $/ \mathrm{g}$ ) but in very high concentrations in Pontoporeia hoyi (68 ng $\alpha$-chlordane/g, $184 \mathrm{ng} \gamma$-chlordane/g) collected in May 1981.

\section{Discussion}

Most samples collected during the study contained measurable levels of toxic organics. These organics included, in order of concentration: PCBs, DDE, dieldrin, $\gamma$-chlordane, and HCB. Other toxicants (DDT, DDD, and $\alpha$-chlordane) were detected in a relatively smaller number of samples.

Levels of toxic organics varied with sampling period. For example, dieldrin concentrations were higher in May 1981 than October 1980 in mysids $>10 \mathrm{~mm}$ in length while $\gamma$-chlordane concentrations were higher in October. Reasons for such temporal variability were not addressed in this study but have been noted by other researchers. Ware \& Addison (1973) related temporal irregularities in PCB residues in plankton collected from the Gulf of St. Lawrence to variability in atmospheric inputs. Temporal variability in body burdens of toxic organics also may be related to seasonal differences in the organism's lipid characteristics. Clayton et al. (1977) suggested that toxic organic 
concentrations in the lower trophic levels of pelagic organisms is controlled by equilibrium partitioning between internal lipid pools and toxicants.

Previous studies (Bache et al. 1972; Veith 1975) have shown that PCB levels increase in certain species of fish with age. Such a trend was not observed for PCBs in the mysids in our study. However, there was some evidence of DDE and dieldrin (and possibly $\gamma$-chlordane) levels being higher in older than younger mysids. More research is required to confirm these possible trends. Higher levels of contaminants in older animals may be related to less efficient physiological mechanisms for excreting or metabolizing assimilated organics or to differences in lipid composition.

Ware \& Addison (1973) showed that PCBs occurred in higher concentrations in the $>76-\mu \mathrm{m}$ plankton size category than the $>202-\mu$ m plankton size category. Our study provided no evidence to support this observation. However dieldrin (and possibly $\gamma$-chlordane) tended to be more abundant in the $>156-\mu \mathrm{m}$ plankton size category.

Some studies suggest that aquatic and marine invertebrates receive a significant amount of their body burden of organic toxicants from their diet (Macek \& Korn 1970; Wyman \& O'Connors 1980). Similarly, there is evidence that bioaccumulation is a function of toxicant concentration in the diet (Reinhert 1972) and increases with higher trophic levels (Woodwell et al. 1967). Benthic organisms often contain relatively high concentrations of toxicants, probably owing to their intimate association with contaminated sediments (Jernelov \& Lann 1971; Yaguchi et al. 1974). Based on this knowledge, it is interesting to compare mysid body burdens of toxicants with dietary levels of contaminants.

Mysid feeding habits are complex. At night, mysids migrate into the thermocline to feed on plankton. Young mysids are herbivorous while adults are omnivorous, consuming invertebrates and large $(>53-\mu \mathrm{m})$ phytoplankton (Bowers \& Grossnickle 1978; Ferrante \& Grossnickle 1979). During the day, mysids are deep in the water column where they may bury themselves partially in the sediments (Beeton 1960; Robertson et al. 1968). Parker(1980) demonstrated in the laboratory that mysids consumed Pontoporeia hoyi. We have observed laboratory animals consuming oligochaetes. Most of the gut material in day-collected mysids (October) was sedimentary in nature. The relative role of planktonic and benthic food items in mysid diets has not been evaluated for Lake Michigan. However, mysids have the potential to obtain toxic organics from both the metalimnion (night) and the sedimentwater interface (day).

Considering only mysids greater than $10 \mathrm{~mm}$ in length, Aroclor 1254 occurred in concentrations similar to the $>76-\mu \mathrm{m}$ and $>156-\mu \mathrm{m}$ plankton size fractions. This suggests that Aroclor 1254 is not bioaccumulated by mysids from their planktonic diet. Aroclor 1242 was slightly more concentrated in mysids than in the plankton. This may suggest some bioaccumulation from the plankton. However, Aroclor 1242 concentrations were comparatively high in Pontoporeia hoyi and dietary amphipods may represent a significant source of this PCB. Mysids appear to have a low assimilation efficiency for PCBs and/or a high efficiency for excreting ingested PCBs. Concentrations of both Aroclors 1242 and 1254 were high in fecal pellets from animals collected while feeding in the metalimnion at night. This phenomenon was first observed by Elder \& Fowler (1977) for marine euphausiids.

DDE tended to occur in higher concentrations in mysids greater than $10 \mathrm{~mm}$ in length than in the two plankton fractions both in October 1980 and May 1981. This suggests a possible bioaccumulation from the plankton diet to mysids. Pontoporeia hoyi DDE concentrations, while greater than in the plankton, were less than those observed in the largest and third largest size category of mysids. Fecal pellets contained low concentrations of DDE which were unlike those observed for PCBs. Thus, mysids appear to be relatively efficient in assimilating DDE from their plankton diet and may be inefficient in excreting DDE. This may account for the possible trend for DDE to increase in concentration in mysids with increased age. Mysids tended to have lower concentrations of $\alpha$-chlordane than in the plankton suggesting no bioaccumulation of this compound from the plankton diet. Trends similar to those mentioned above were not apparent for $\gamma$-chlordane, dieldrin, or HCB.

Sediment concentrations of toxic organics reported by Frank et al. (1981) for the Grand Haven deposition basin provide an upper estimate of concentrations at our site which is several kilometers to the north in a nondepositional area. Sedimentary concentrations of contaminants tend to be lower 
than in the biota, possibly owing to the lower organic content of abiotic material. It is pertinent to compare contaminant levels in the sediments with those of the ampiphod Pontoporeia hoyi and Mysis relicta. The mean PCB concentration for the Grand Haven depositional basin was $17.1 \mathrm{ng} / \mathrm{g}$ (Frank et al. 1981). We observed PCB concentrations of $513 \mathrm{ng}$ Aroclor 1242/g and $792 \mathrm{ng}$ Aroclor 1254 in Pontoporeia hoyi. PCB concentrations were greater in amphipods than mysids.

Frank et al. (1981) determined a mean sedimentary DDT concentration of $7.4 \mathrm{ng}$ DDT/g, $11.4 \mathrm{ng}$ TDE/g (synonymous with DDD), and $11.4 \mathrm{ng}$ $\mathrm{DDE} / \mathrm{g}$ for the Grand Haven depositional basin. We did not detect DDT in amphipods in May while DDE (154 ng/g) and DDD (96 ng/g) concentrations were high. Like Aroclor 1242 and 1254, DDD tended to occur in higher concentrations in amphipods than mysids suggesting a greater bioaccumulation in organisms with strong sedimentary affinities. Alternatively, there may be differences between mysid and amphipod physiology with respect to toxic organic metabolism.

Mean sedimentary concentration for chlordane in the Grand Haven depositional basin was 17.1 $\mathrm{ng} / \mathrm{g}$ (Frank et al. 1981). This contrasts with a mean concentration of $183.5 \mathrm{ng} \gamma$-chlordane/ $\mathrm{g}$ and 68.3 ng $\alpha$-chlordane/g for Pontoporeia hoyi. Chlordane values were greater in amphipods than in mysids.

Frank et al. (1981) did not report HCB and dieldrin concentrations in the Grand Haven depositional basin. We observed that dieldrin occurred in much higher concentrations in amphipods in May 1981 than in mysids while HCB values were also somewhat higher in amphipods.

Since only one sculpin was analyzed for toxic organics, we must interpret trends with caution. It is interesting to note that Aroclor 1254 concentrations were as high in the sculpin as in amphipods and mysids while Aroclor 1242 concentrations were low. This suggests that sculpins excrete or metabolize Aroclor 1242 or else are inefficient in assimilating the lower chlorine-containing biphenyls which make up this Aroclor. Since sculpins consume both Pontoporeia hoyi and Mysis relicta (Scott \& Crossman 1973: Evans, unpubl. data), it was somewhat unexpected that PCBs occurred in similar concentrations in the sculpin and its prey. This was observed not only for PCBs, but also DDE, and $\alpha$-and $\gamma$-chlordane. Dieldrin concentrations were lower in the sculpin than its prey.

Results presented here are the first of a developing study. However, our study suggests that mysids have a role in both the downward transport and the recycling of toxic organics in the Lake Michigan ecosystem. Furthermore, the study suggests that the specific transport pathways vary with the compound. For example, PCBs do not bioaccumulate in mysids with age and appear to be relatively efficiently excreted and/or inefficiently assimilated. Conversely, mysids do appear to accumulate DDE with age and had higher DDE concentrations than their planktonic diet.

Downward movement of contaminants occurs through a variety of passive sinking processes and the active movement of migrators. Mysids transport contaminants to the lake bottom directly by ingesting plankton from the upper layers of the lake and migrating to the sediments. These toxic organics then may be excreted, egested, lost through moults, or released to the sediments on the death of the mysid. The passive sinking of fecal pellets produced in the upper layers of the ocean is an important transport route for a variety of contaminants in marine systems (Elder \& Fowler 1977; Turner \& Ferrante 1979) and may have a similarly significant role in Lake Michigan. Mysids feeding in the metalimnion at night produce fecal pellets which, if released in the upper layers, will sink to the sediments. Sinking rates are rapid $(80-170 \mathrm{~m} /$ day; Evans, unpubl. data) and many probably reach the sediments intact before microbial activity disrupts the peritrophic membrane. However, coprophagous copepods that feed on fecal pellets may recycle toxicants. Examination of sediment trap collections from our study site has determined that more than half (by volume) of the aggregated particulates collected below $15 \mathrm{~m}$ consisted of fecal pellets and fecal matter (Glover \& Evans 1981).

Marine studies have focussed on downward transport processes of contaminants and generally have not considered recycling from ocean sediments. Given the fact that many of these studies were conducted in waters more than $1000 \mathrm{~m}$ deep, it unlikely that a significant amount of toxic material is recycled back into the surface layers. Conversely, significant recycling may occur in lakes where depths seldom exceed a few tens of meters and the surface and sediments are in closer proximity. Our study suggests that biological recycling can occur 
through several routes. One route is through amphipods taking up contaminants from the sediments or detrital matter and the subsequent consumption of these organisms by fish and mysids. Mysids recycle contaminants through several routes. These include uptake from sedimentary material, from benthic prey organisms, and from detrital matter sinking out of the water column. By vertically migrating into the surface at night, mysids transport some material up into the upper regions of the lake. This material will continue to recycle through the Lake Michigan ecosystem if the toxicant is excreted, egested, lost with moults, or if the mysid is consumed by fish.

\section{Acknowledgments}

This research was sponsored by Michigan Sea Grant, Office of Sea Grant, NOAA. Special thanks are extended to Captain Clifford Tetzloff and Glen Tompkins of the R/V Mysis for their cheerful cooperation and assitance during the field study. Contribution number 314, Great Lakes Research Division, University of Michigan.

\section{References}

Bache, C. A., Serum, T. G., Young, W. D. \& List, D. J., 1972. Polychlorinated biphenyl residues: accumulation in Cayuga lake trout with age. Science 177: 1191-1192.

Beeton, A. M., 1960. The vertical migration of Mysis relicta in Lakes Huron and Michigan. J. Fish. Res. Bd Can. 17: 517-539.

Bidleman, T. F., Matthews, J. R., Olney, C. E. \& Rice, C. P., 1978. Separation of PCB, chlordane, and p, $\mathrm{p}^{\prime}$-DDT from toxaphene by silicic acid column chromatography. J. Ass. offic. analyt. Chem. 61: 820-828.

Bowers, J. A. \& Grossnickle, N. E., 1978. The herbivorous habits of Mysis relicta in Lake Michigan. Limnol. Oceanogr. 23: 767-776.

Clayton, J. R., Pavlou, S. P. \& Breitner, N. F., 1977. Polychlorinated biphenyls in coastal marine zooplankton and bioaccumulation by equilibrium partitioning. Envir. Sci. Technol. 11: 676-682.

Committee on the Assessment of Polychlorinated Bephenyls in the Environment, 1979. Polychlorinated Biphenyls. National Academy of Sciences. $182 \mathrm{pp}$.

Elder, D. L. \& Fowler, S. W., 1977. Polychlorinated biphenyls: penetration into the deep ocean by zooplankton fecal pellet transport. Science 197: 459-460.

Ferrante, J. G. \& Grossnickel, N., 1979. The relationship of the life history and population size structure of Mysis relicta on the cycling of silica in Lake Michigan. Abst. 42 nd Annual Meeting of Am. Soc. Limnol. Oceanogr.

Frank, R., Thomas, R. L., Holdrinet, M., Kemp, A. L. W. \& Brown, H. E., 1979. Organochlorine insecticides and PCB in surficial sediments (1968) and sediment cores (1976) from Lake Ontario. J. Gt Lakes Res. 5: 18-27.

Frank, R., Thomas, R. L., Braun, H. E., Rasper, J. \& Dawson, R., 1980. Organochlorine insecticides and PCB in the surficial sediments of Lake Superior (1973). J. Gt Lakes Res. 6: $113-120$.

Frank, R., Thoma, R. L., Braun, H. E., Gross, D. L. \& Davies, T. T., 1981. Organochlorine insecticides and PCB in surficial sediments of Lake Michigan (1975). J. Gt Lakes Res. 7: 42-50.

Glooschenko, W. A., Strachan, W. M. J. \& Sampson, R. C. J., 1976. Distribution of pesticides and polychlorinated biphenyls in water, sediments, and seston of the upper Great Lakes 1974. Pest. Monit. J. 10:61-67.

Glover, R. \& Evans, M. S., 1981. The composition of particulates in Lake Michigan using S.E.M. and light microscope techniques. Micron 12: 297-298.

International Joint Commission, 1979. Great Lakes Water Quality. App. 15.

Janssen, J. \& Brandt, S. B., 1980. Feeding ecology and vertical migration of adult alewives (Alosa pseudoharengus) in Lake Michigan. J. Fish. Res. Bd Can. 37: 177-184.

Jernelov, A. \& Lann, H., 1971. Mercury accumulation in food chains. Oikos 22: 403-406.

Kaiser, K. L. E. \& Valdmanis, I., 1978. Organochlorine contaminants in a sea lamprey (Petromyzon marinus) from Lake Ontario. J. Gt Lakes Res. 4: 234-236.

Macek, K. J.\& Korn, S., 1970. Significance of the food chain in DDT accumulation by fish. J. Fish. Res. Bd Can. 27: 1496-1498.

Matsumura, F., 1975. Toxicology of Insecticides. Plenum Press, New York. 503 pp.

McComish, T.S.\& Miller, W. G., 1976. Notes on the biology of the lake trout and other selected Salmonidae in the Indiana waters of Lake Michigan. Proc. ind. Acad. Sci. 85: 161-165.

Morgan, M. D. \& Beeton, A. M., 1978. Life history and abundance of Mysis relicta in Lake Michigan. J. Fish. Res. Bd Can. 35: 1165-1170.

Mozley, S. C. \& Howmiller, R. P., 1977. Environmental status of the Lake Michigan Region. Vol. 6: Zoobenthos of Lake Michigan. Argonne National Laboratory.

Murphy, T. J. \& Rzeszutko, C. P., 1977. Precipitation inputs of PCBs to Lake Michigan. J. Gt Lakes Res. 3: 305-312.

Parker, J. I., 1980. Predation by Mysis relicta on Pontoporeia hoyi: a food chain link of potential importance in the Great Lakes. J. Gt Lakes Res. 6: 164-166.

Reinhert, R. E., 1972. Accumulation of dieldrin in an alga (Scendesmus obliquus), Daphnia magna, and the guppy (Poecilia reticulata). J. Fish. Res. Bd Can. 29: 1413-1418.

Robertson, A., Powers, C. F. \& Anderson, R. F., 1968. Direct observation on Mysis relicta from a submarine. Limnol. Oceanogr. 13: 700-702.

Rosa, J. L., 1976. A simple system for recovering fecal pellets in quantity. Deep Sea Res. 23: 995-997.

Scott, W. B. \& Crossman, E. J., 1973. Freshwater fishes of 
Canada. Fish. Res. Bd Can., Bull. 184.

Strachan, W. M. J. \& Huneault, H., 1979. Polychlorinated biphenyls and organochlorine particulates in Great Lakes precipitation. J. Gt Lakes Res. 5: 61-68.

Suns, K. \& Rees, G. A., 1978. Organochlorine contaminant residues in young-of-the-year spottail shiners from Lakes Ontario, Erie, and St. Clair. J. Gt Lakes Res. 4: 23-233.

Turner, J. T. \& Ferrante, J. G., 1979. Zooplankton fecal pellets in aqautic systems. Bio Science 29: 670-677.

Veith, G. D., 1975. Baseline concentrations of polychlorinated biphenyls and DDT in Lake Michigan fish - 1971. Pest. Monit. J. 9: 21-29.

Ware, D. M. \& Addison, R. F., 1973. PCB residues in plankton from the Gulf of St. Lawrence. nature 246: 519-521.

Weininger, D., 1978. Accumulation of PCBs in lake trout in Lake Michigan. Ph. D. thesis, Univ. Wisc.-Madison.
Wells, L., 1968. Daytime distribution of Pontoporeia affinis off bottom in Lake Michigan. Limnol. Oceanogr. 13: 703-705.

Wells, L., \& Beeton, A. M., 1963. Food of the bloater, Coregonus hoyi, in Lake Michigan. Trans. Am. Fish. Soc. 92: 245-255.

Woodwell, G. M., Wurster, C. F., Jr. \& Isaacson, P. A., 1967. DDT residues in an east coast estuary: a case of biological concentration of a persistent insecticide. Science 156: $821-824$.

Wyman, K. D. \& O'Connors, H. B. Jr., 1980. Implications of short-term PCB uptake by small estuarine copepods (genus Acartia) from PCB-contaminated water, inorganic sediments, and phytoplankton. Est coast. mar. Sci. 11: 121-131.

Yaguchi, E. M., Waller, B. J.\& Marshall, J. S., 1974. Plutonium distribution in Lake Michigan biota. Proc. 17 th Conf. Great Lakes Res.: 150-157. 